\title{
Plant Pathogenic Alternaria Species in Libya
}

\author{
Abdalla M. El-Alwany \\ Department of Plant Protection, Faculty of Agriculture, Benghazi University, Benghazi, Libya \\ Email: alwanyalwa@gmail.com
}

Received 10 June 2015; accepted 26 June 2015; published 3 July 2015

Copyright (C) 2015 by author and OALib.

This work is licensed under the Creative Commons Attribution International License (CC BY). http://creativecommons.org/licenses/by/4.0/

c) $\underset{\mathrm{EY}}{ }$ Open Access

\begin{abstract}
This study was carried out to identify unknown Alternaria species or less known as plant pathogenic anamorphic fungi from Benghazi District. Plant materials with fungal signs and symptoms were collected and examined to identify causal agents. Five species-A. brassicae (on Eruca sativa), A. longipes (on Nicotiana glauca), A. tenuissima (on Ficus carica), A. triticicola (on Hordeum vulgare L.) and Alternaria state of Pleospora infectoria (on Avena sativa)-were reported as plant pathogenic and new to Libyan mycobiota.
\end{abstract}

\section{Keywords}

\author{
Alternaria Species, A. brassicae, A. longipes, A. tenuissima, A. triticicola and Alternaria State of \\ Pleospora infectoria, in Libya
}

Subject Areas: Biodiversity, Plant Science

\section{Introduction}

Alternaria belongs to the division Deuteromycota with several species. Its multicellular pigmented spores are produced in chains or in branching fashions. The spores are broadest near the base and taper gradually to an elongate beak. The genus is characterized by the formation of polymorphous conidia either singly or in short or longer chains and provided with cross, longitudinal as well as oblique septa and having longer or short beaks. The spores of these polyphagus fungi occur commonly in the atmosphere and also in the soil. The telomorphs (sexual stage) are known in a very few species and placed in the genus Pleospora of Loculoascomycetes (under sub-division: Ascomycotina), in which sleeper-shaped, muriformascospores are produced in bitunicateasci [1]. Works pertaining to the collection, isolation and characterization of other Alternaria species are also being carried out for its elaborate studies [2]. Alternaria fungus has about one hundred species which can be found in various places all over the world. Many of them are important pathogens of plants and cause important economical disease in wide range of hosts (more than 380) [3] [4]. It is associated with a wide variety of substrates including seeds, plants, agricultural products, animals, soil and the atmosphere. Several taxa are also important postharvest pathogens [5]. They act as plant pathogens, weak facultative parasites, saprophytes and endophytes 
[6]. Conidiophores of majority of the species of Alternaria produce asexual spores (conidia) measuring between $160-200 \mu \mathrm{m}$ long. Under in vitro conditions, sporulation occurs at a temperature range of $8^{\circ} \mathrm{C}-24^{\circ} \mathrm{C}$, where mature spores occur after $14-24 \mathrm{~h}$. Optimum temperatures are between $16^{\circ} \mathrm{C}$ and $24^{\circ} \mathrm{C}$ where sporulation time ranges from 12 to $14 \mathrm{~h}$. Moisture in the presence of rain, dew or high humidity are essential for infection and a minimum of $9-18 \mathrm{~h}$ are required for majority of the species [7].

Among the different diseases caused by the genus Alternaria, blight disease is one of the most dominant diseases that cause average yield loss in the range of 32\% - 57\% [8]. Symptoms of this disease include presence of irregular, often circular brown to dark brown color leaf spots on the leaves with concentric lines inside the spots. Often the circular spots coalesce to form large patches resulting in the leaf blight [9].

A number of plant pathogenic fungi including Alternaria produce toxins that can damage plant tissues. Toxins are often classified as host selective (host specific) or nonspecific. Host-selective toxins (HSTs) are toxic only to host plants of the fungus that produces the toxin. In contrast, nonspecific toxins can affect many plants regardless of whether they are a host or non-host of the producing pathogen. Ref. [10] classified toxins of plant pathogens as a pathogenicity factor or a virulence factor by considering the possible involvement of toxins in pathogenesis: pathogenicity is the ability to cause disease (a qualitative term), whereas virulence refers to the extent or severity of the disease caused (a quantitative term). Most HSTs are considered to be pathogenicity factors, which the fungi producing them require to invade tissue and induce disease [11] [12].

The major sources of transport of these pathogens are the infected seeds with spores on the seed coat or the presence of mycelium under the seed coat. The dissemination of spores occurs by wind, water, tools and animals. The fungus can survive in susceptible weeds or perennial crops [13].

The aim of this study was to define a number of Alternaria species associated with blighted cultivated and wild hosts in Benghazi as Libyan mycobiota.

\section{Material and Methods}

Plant materials with fungal signs and symptoms were collected from wild or cultivated areas eastern Benghazi district as shown in (Figure 1). Fungal structures were mounted in 50\% Lactic acid and examined using a BLP 4000 Hamilton microscope. Images were taken by a digital camera (IT-305WC). Measurements were taken in $50 \%$ Lactic acid, based on 40 - 50 conidia, conidiophores and other fungal structures. For photography, more than one photograph was taken for each specimen and selected photos were merged together and arranged into a single photo for each specimen in Adope Photoshop (Ver. 7.0 ME). Identification of taxa is based on the keys and descriptions of [14]-[18]. All names checked with MycoBank (http://www.mycobank.org) and nomenclature follows this online database [19]. For each species descriptions, photographs of the conidiophores and

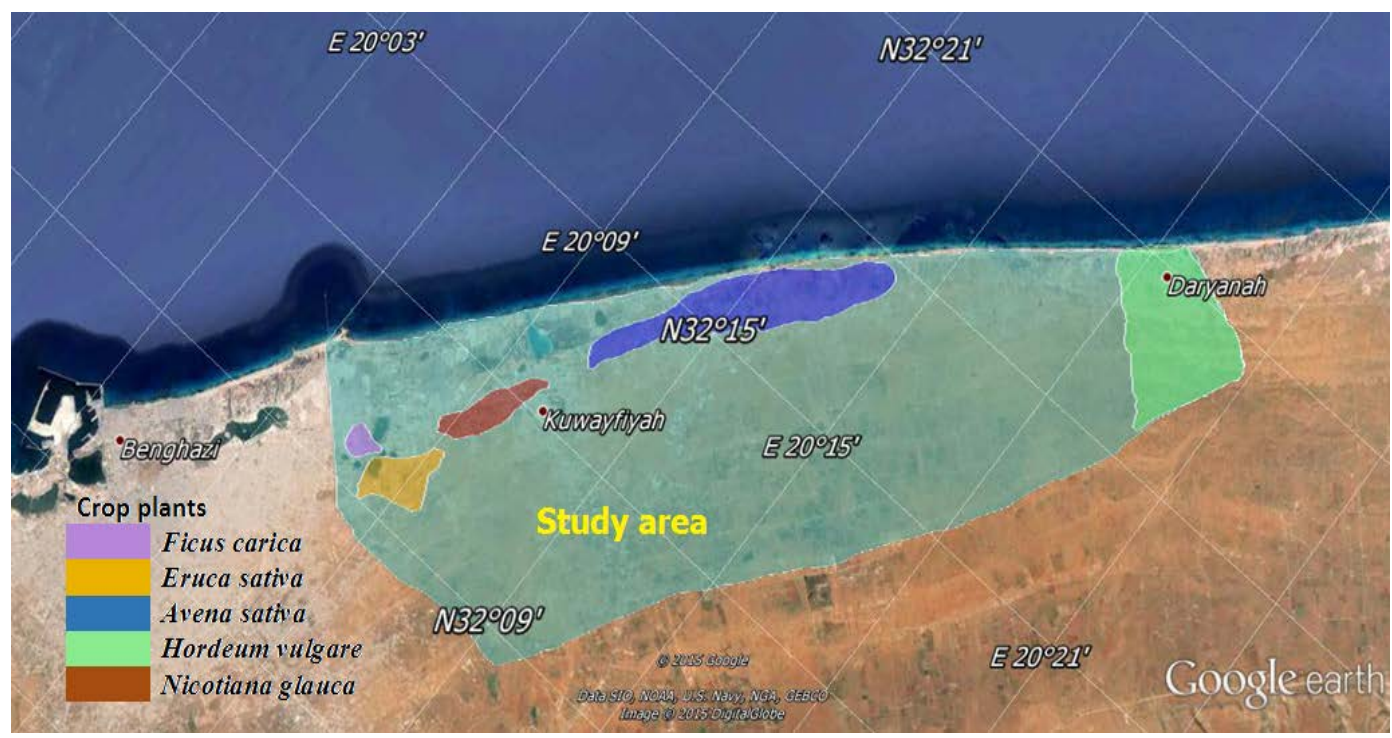

Figure 1. A map of study area showed the crop plant sites in the eastern of Benghazi (Lat: $20^{\circ} 05^{\prime} \mathrm{E} \& 20^{\circ} 21^{\prime} \mathrm{E}$. Lon: $\left.32^{\circ} 08^{\prime} \mathrm{N} \& 32^{\circ} 21^{\prime} \mathrm{N}\right)$. 
conidia are provided.

\section{Results and Discussion}

Results of this study proved existence of five species of Alternaria on five host plants including: Alternaria brassicae on Eruca sativa M., Alternaria longipes on Nicotiana glauca G., Alternaria tenuissima on Ficus carica L., Alternaria triticicola on Hordeum vulgare L. and Alternaria state of Pleospora infectoria on Avena sativa L. Detailed descriptions were as follows:

\subsection{Alternaria brassicae (Berk.) Sacc., Michelia 2 (6): 172 (1880)}

On leaves of Erucasativa forming circular, zonate, light brown to grayish or dark brown spots up to $12 \mathrm{~mm}$. diam. then coalescing; on the mid ribs of the leaves the spots are oblong or linear and sunken (Figure 2(A)). Conidiophores arising in groups of 2 - 10 or more from the hyphae, emerging through stomata, usually simple, erect or ascending, straight or flexuous, frequently geniculate, more or less cylindrical but often slightly swollen at the base, septate, mid-pale grayish olive, smooth, up to $170 \mu$ long, 6 - $11 \mu$ thick, bearing one to several small but distinct conidial scars (Figure 2(B)). Conidia solitary or occasionally in chains of up to 4, acropleurogenous arising through small pores in the conidiophores wall, straight or slightly curved, obclavate, rostrate, with 6 - 19 (usually 11 - 15) transverse and 0 - 8 longitudinal or oblique septa, pale or very pale olive or grayish olive, smooth or, infrequently, very inconspicuously warted, 75 - $350 \mu$ long and usually 20 - $30 \mu$ (sometimes up to $40 \mu$ ) thick in the broadest part, the beak about $1 / 3$ to $1 / 2$ the length of the conidium and $5-9 \mu$ thick (Figure 2(B)).

\subsection{Alternaria longipes (Ellis \& Everh.) E. W. Mason, Mycological Paper 2: 19 (1928)}

The first symptoms of brown spot disease are small, circular, dark-brown lesions on the lower leaves. The lesions enlarge as the leaves mature and are surrounded by an irregular, yellow halo. The halo is caused by the secretion of toxins. Often there are numerous lesions, about $25 \mathrm{~mm}$ in diameter, which may coalesce and affect more than $80 \%$ of the leaf area. Large infected leaves senesce prematurely and the affected part of a leaf may be yellow when the rest is dark green. A uniform infection, covering up to about $10 \%$ of leaf area (Figure 3(A)).

Conidiophores arising singly or in groups, erect or ascending, simple or loosely branched, straight or flexuous, cylindrical, septate, rather pale olivaceous brown, up to $80 \mu$ long, 3 - $5 \mu$ thick, with 1 or several conidial scars (Figure 3(B)). Conidia sometimes solitary but usually in chains, boclavate, rostrate, pale to mid pale brown, smooth or verruculose, overall length 35 - 110 (69) $\mu$, body of conidium 11 - 21 (14) $\mu$ thick in the broadest part, tapering gradually into the pale brown beak which is usually $1 / 3$ to $1 / 2$ the total length, 2 - $5 \mu$ thick and often slightly swollen at the tip; there are $3-7$, usually 5 - 6 transverse septa and 1 to several longitudinal or oblique septa (Figure 3(B)).
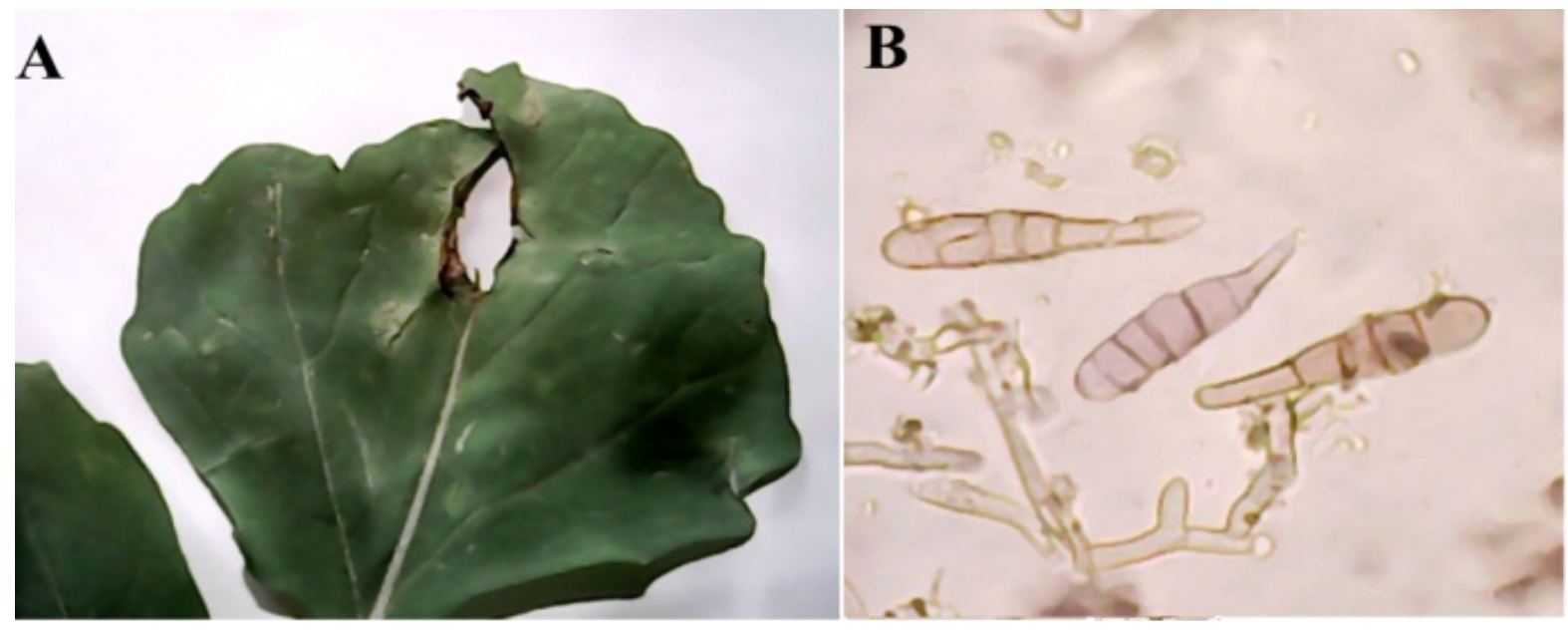

Figure 2. Alternaria brassicae: (A) Dark brown zonate spots on Eruca sativa; (B) Conidia and conidiophores $(\times 1280)$. 


\subsection{Alternaria tenuissima (Nees) Wiltshire, Transactions of British Mycological Society 18 (2): 157 (1933)}

The symptoms recorded on Ficus carica leaves were small, circular, brown necrotic spots all over the foliage. The spots gradually enlarged in size and later became irregular in shape or remained circular with concentric rings or zones. In the later stage of infection, these spots coalesce causing blighting of leaves resulting in withering, extensive drying and shedding of leaves. The spots were initially light brown and later turned dark brown (Figure 4(A)).

Conidiophres solitary or in groups, simple or branched, straight or flexuous, more or less cylindrical, septate, pale or mid pale brown, smooth, with 1 or several conidial scars, up to $115 \mu$ long, 4 - $6 \mu$ thick (Figure 4(B)). Conidia solitary or in short chains, straight or curved, obclavate or with the body of the conidium ellipsoidal tapering gradually to the beak which is up to half the length of the conidium, usually shorter, sometimes tapered to a point but more frequently swollen at the apex where there may be several scars, pale to mid clear golden brown, usually smooth, sometimes minutely verruculose, generally with 4-7 transverse and several longitudinal or oblique septa, slightly or not constricted at the septa, overall length 22 - 95 (54) $\mu, 8$ - 19 (13.8) $\mu$ thick in the broadest part; beak 2 - $4 \mu$ thick, swollen apex 4 - $5 \mu$ wide (Figure 4(B)).

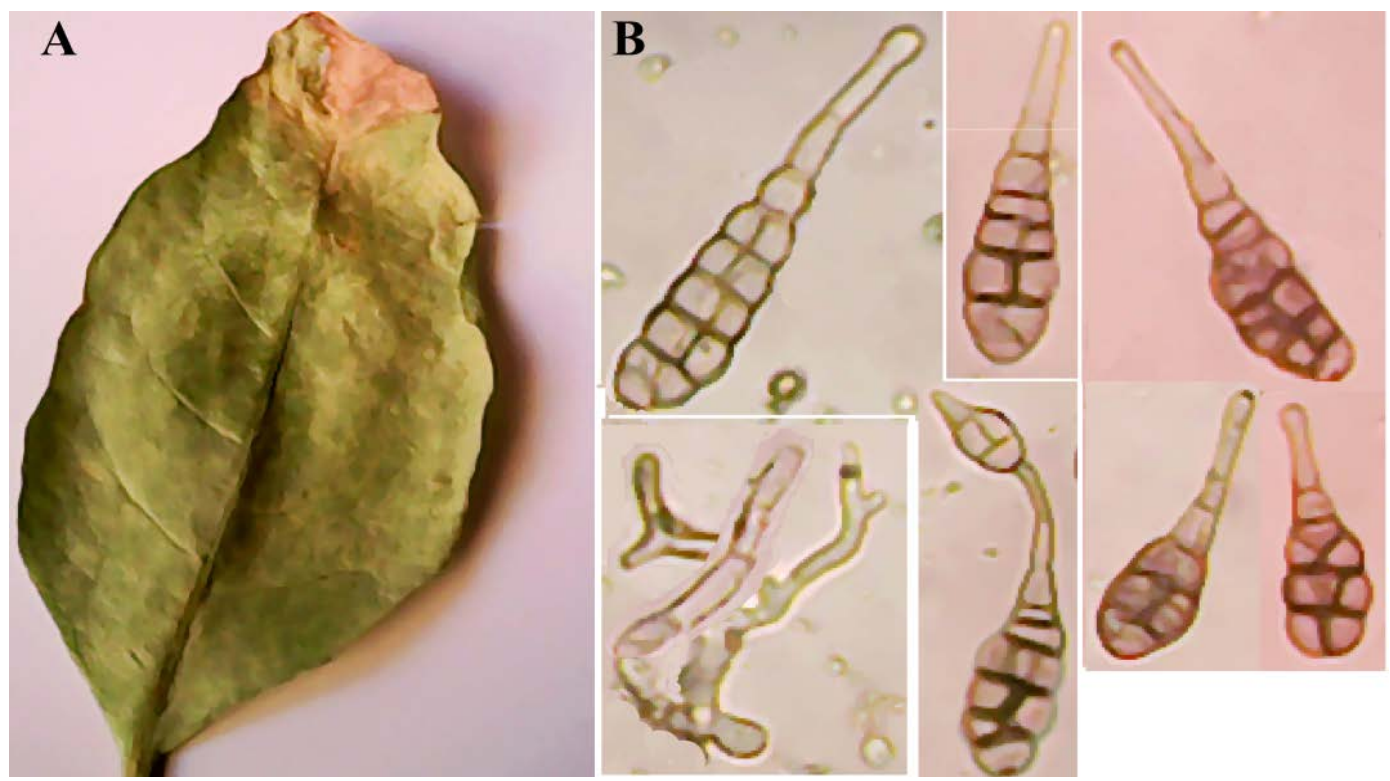

Figure 3. Alternaria longipes: (A) Infection covering up to $10 \%$ of leaf area on Nicotiana glauca; (B) Conidia and conidiophores $(\times 1280)$.
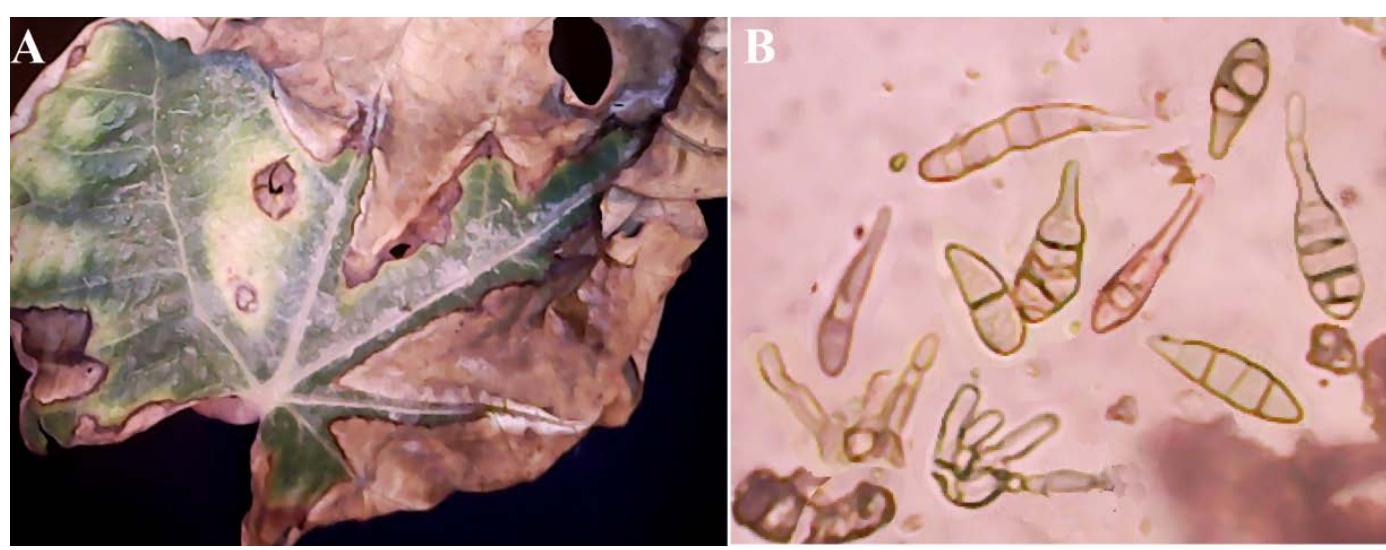

Figure 4. Alternaria tenuissima: (A) Leaves of Ficus carica; spots coalesce causing blighting in withering, extensive drying and shedding; (B) Conidia and conidiophores $(\times 1280)$. 


\subsection{Alternaria triticicola V. G. Rao, Mycopathologia et Mycologia Applicata 23 (4): 313} (1964)

In natural field infections it was observed that elongated necrotic lesions with dark brown margins develop progressively from lower to upper leaves. A yellow halo was sometimes seen around the lesions. Sometimes the margin of top leaves became brittle when dried and the tissue tore (Figure 5(A)).

Conidiophores often emerging through stomata in fascicles, simple or branched, straw colored, up to $100 \mu$ long, 5 - $9 \mu$ thick (Figure 5(B)). Conidia solitary or in chains of 2 - 3, broadly fusiform to obclavate, rostrate, pale to mid pale golden brown, smooth or occasionally minutely verruculose, 50 - $170 \mu$ long, 12 - $35 \mu$ thick; body with 3 - 10 transverse and several longitudinal or oblique septa; beak much shorter than the body, 4 - $6 \mu$ thick along of its length but often swollen to 7 - $8 \mu$ at the apex (Figure 5(B)).

\subsection{Alternaria State of Pleospora infectoria Fuckle, Symb. Mycol. 132 (1870)}

Infection is first evident as small, oval, discoloured lesions irregularly scattered on the leaves. As the lesions enlarge they become dark brown to grey and irregular in shape. Some are surrounded by a bright-yellow marginal zone. As the disease progresses, several lesions coalesce to cover large areas, resulting in the death of the entire leaf (Figure 6(A)).

Conidiophores arising singly or in small groups, simple or branched, straight or flexuous, sometimes geniculate, pale to mid golden brown, smooth, up to $80 \mu$ long, 3 - $6 \mu$ thick, with 1 or several conidial scars (Figure 6(B)). Conidia formed in long, often branched chains, conical, obpyriform or obclavate, tapering gradually to a beak which is up to half the total length of the conidium and often swollen at its tip, pale to mid golden brown, distinctly verrucose and rather thick-walled, with up to 8 transverse septa usually close together and several longitudinal or oblique septa, overall length 20 - 70 (50) $\mu$, 9 - 18 (14) $\mu$ thick in the broadest part; 3 - $5 \mu$ wide (Figure 6(B)).

Conidial and conidiophores measurements in (Table 1) showed clear differences either in conidial or conidiophores measurements among tested species. Conidiophores of $A$. brassicae showed greater length and thickness $(150 \mu, 8 \mu)$ compared to other species, while A. Pleospora infectoria showed the least length and thickness $(71 \mu, 4 \mu)$. This trend changed in conidial measurements in which A. triticicola takes the first place in conidial length and thickness, and septal features, while A. Pleospora infectoria takes the last place. A. brassicae showed greater beak length and thickness followed by Alternaria longipes, while Alternaria triticicola had the least beak

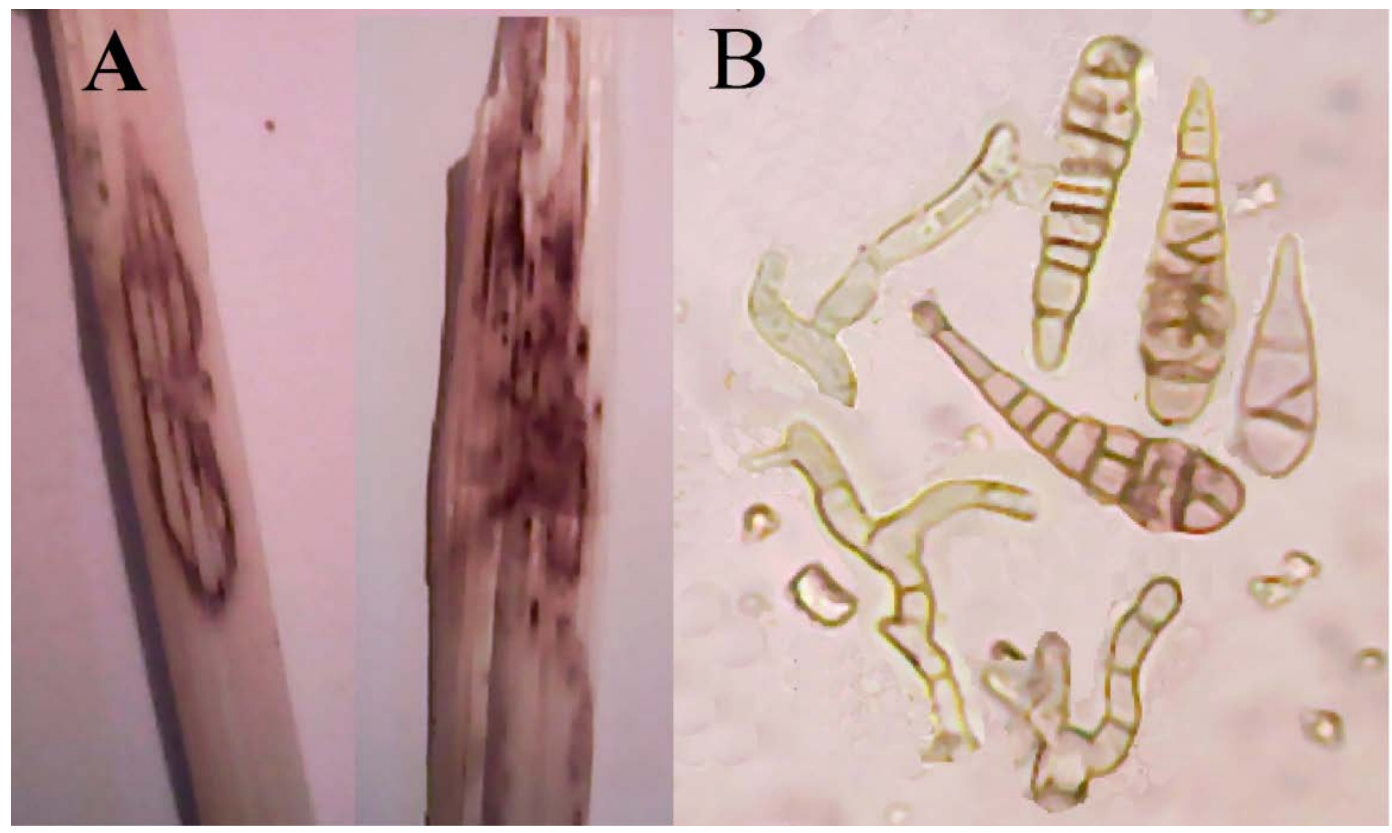

Figure 5. Alternaria triticicola: (A) Elongated necrotic lesions with dark brown margins and brittle margins of the top of leaves; (B) Conidia and conidiophores $(\times 1280)$. 

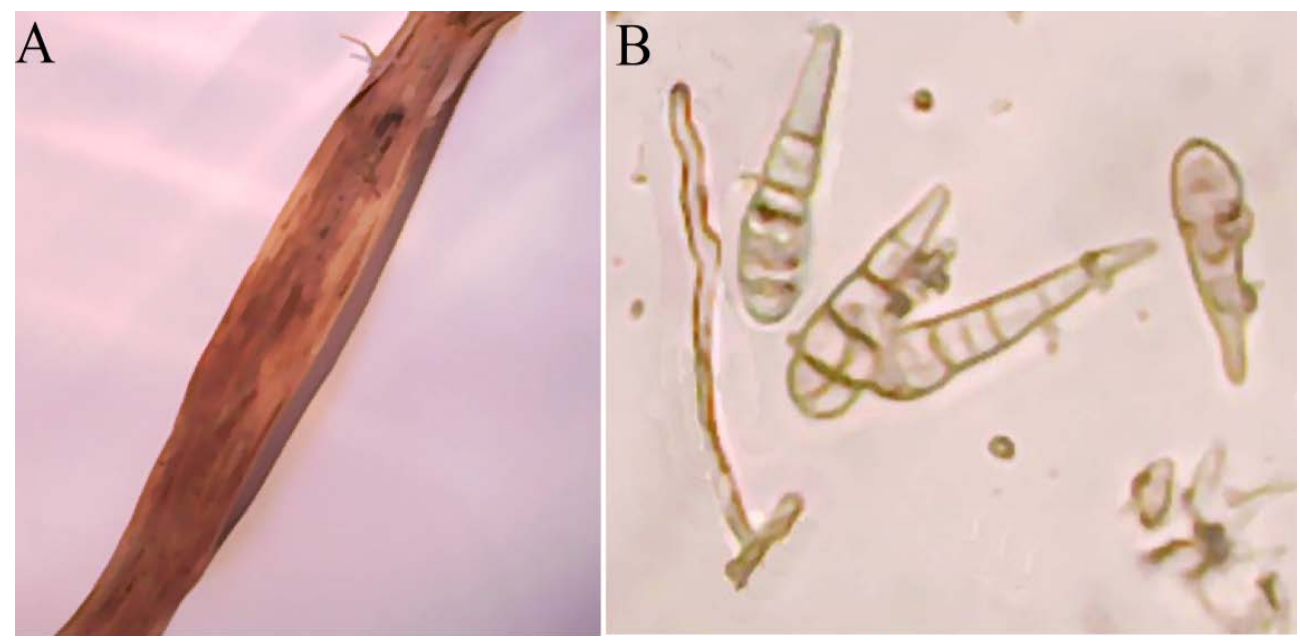

Figure 6. Alternaria state of pleospora infectoria: (A) Dark brown to grey lesions irregular in shape surrounded by a bright-yellow marginal zone; (B) Conidia and conidiophores $(\times 1280)$.

Table 1. Mean(s) of conidiophores and conidia measurements $(n=40)$, for the five species; A. brassicae, A. longipes, A. tenuissima, A. triticicola and Alternaria state of Pleospora infectoria.

\begin{tabular}{|c|c|c|c|c|c|c|c|c|c|}
\hline \multirow{3}{*}{ Alternaria species } & \multirow{2}{*}{\multicolumn{2}{|c|}{ Conidiophores }} & \multicolumn{7}{|c|}{ Conidial features } \\
\hline & & & \multicolumn{2}{|c|}{ Dimensions } & \multicolumn{3}{|c|}{ Septal No. } & \multicolumn{2}{|c|}{ Beak } \\
\hline & Length $(\mu)$ & Thick $(\mu)$ & Length $(\mu)$ & Thick $(\mu)$ & Transverse & Longitudinal & Oblique & Length $(\mu)$ & Thick $(\mu)$ \\
\hline Alternaria brassicae & 150 & 8 & 115 & 24 & 7 & 1 & 0 & 48 & 7 \\
\hline Alternaria longipes & 68 & 6 & 102 & 20 & 6 & 2 & 1 & 42 & 6 \\
\hline Alternaria tenuissima & 57 & 5 & 78 & 9.5 & 4 & 1 & 0 & 35 & 3.5 \\
\hline Alternaria triticicola & 88 & 8 & 118 & 28 & 8 & 2 & 1 & 6 & 5 \\
\hline $\begin{array}{c}\text { Alternaria pleospora } \\
\text { infectoria }\end{array}$ & 71 & 4 & 47 & 13 & 5 & 2 & 0 & 21 & 6 \\
\hline
\end{tabular}

length. All these measurements were close to a large extent with that recorded by [14] [15], which refer to the belief that the diversity of spatial and climatic conditions do not play a significant role in the difference among conidial patterns.

There are more than 300 species of Alternaria that can be found in most situations in the environment. Some species are plant pathogens that, collectively, cause a range of diseases with economic impact on a large variety of important agronomic host plants including, ornamentals, fruit, vegetable and other crops. Leaf spots caused by Alternaria rarely kill plants but they can reduce their aesthetic quality and commercial value. The necrotrophic nature of the Alternaria species leads to extensive damage of the plant and harvest product [20] [21].

The main economic impacts result from the effect on germination and the subsequent seedling blight. Seed with reduced germination due to infection may not be saleable as certified [22]. Ref. [23] noted that Alternaria species can pose a threat to the production of food items such as young seedlings of Chinese radish (Raphanus sativus var. hortensis) which is a popular food garnish in Japan. Likewise, in the USA, Alternaria spot on the edible leaves, heads and other parts of vegetables can make them unsaleable [24]. The metabolites from plant pathogenic Alternaria usually toxic to plants and are called phytotoxins. They were further divided into hostspecific and host non-specific toxins [25]. The Alternaria specific toxins cause necrosis on leaves of susceptible cultivars at concentrations as low as $10^{-8}$ to $10^{-9} \mathrm{M}$ and no necrosis on leaves of resistant cultivars even at higher concentrations [26].

Alternaria species also produce types of toxins that are non-host specific. In addition to AB-toxin, other toxic substances including desipeptides and fucicoccin-like compounds are also being produced by different pathotypes of Alternaria [27] [28]. 


\section{Conclusion}

Based on available records, all these Alternaria species are new recorded on the mentioned host plants, which are considered as new addition to Libyan mycobiota.

\section{References}

[1] Neeraj, B. and Verma, S. (2010) Alternaria Diseases of Vegetable Crops and New Approaches for Its Control. Asian Journal of Experimental Biological Sciences, 1, 681-692. http://www.ajebs.com/vol3/33.pdf

[2] Mamgai, A., Roychowdhury, R. and Tah, J. (2013) Alternaria Pathogenicity and Its Strategic Controls. Research Journal of Biology, 1, 1-9. http://researchjournalofbiology.weebly.com/uploads/1/9/5/3/19535339

[3] Kirk, P.M., Cannon, P.F., Minter, D.W. and Stalpers, J.A. (2008) Dictionary of the Fungi. 10th Edition, Wallingford, CABI, 22. http://www.slideshare.net/fitolima/dictionary-of-fungi-kirk-et-al-2008-10a-edicao

[4] Nikoo, K., Zamanizadeh, H., Morid, B., Taheri, H. and Hajmansor, S. (2012) Study on Pathogenic and Genetic Diversity of Alternaria alternata Isolated from Citrus Hybrids of Iran, Based on RAPD-PCR Technique. European Journal of Experimental Biology, 2, 570-576. www.pelagiaresearchlibrary.com

[5] Woudenberg, J.H.C., Groenewald, J.Z., Binder, M. and Crous, P.W. (2013) Alternaria Redefined. Studies in Mycology, 75, 171-212. http://www.ncbi.nlm.nih.gov/pmc/articles/PMC3713888/ http://dx.doi.org/10.3114/sim0015

[6] Thomma, B.P.H.J. (2003) Alternaria spp.: From General Saprophyte to Specific Parasite. Molecular Plant Pathology, 4, 225-236. http://onlinelibrary.wiley.com/doi/10.1046/j.1364-3703.2003.00173.x/epdf http://dx.doi.org/10.1046/j.1364-3703.2003.00173.x

[7] Humpherson-Jones, F.M. and Phelps, K. (1989) Climatic Factors Influencing Spore Production in Alternaria brassicae and Alternaria brassicicola. Annals of Applied Biology, 114, 449-458. http://onlinelibrary.wiley.com/doi/10.1111/j.1744-7348.1989.tb03360.x/pdf http://dx.doi.org/10.1111/j.1744-7348.1989.tb03360.x

[8] Conn, K.L. and Tewari, J.P. (1990) Survey of Alternaria Black Spot and Sclerotinia Stem Rot in Central Alberta in 1989. Canadian Plant Disease Survey, 70, 66-67.

[9] Valkonen, J.P.T. and Koponen, H. (1990) The Seed-Borne Fungi of Chinese Cabbage (Brassica pekinensis), Their Pathogenicity and Control. Plant Pathology, 39, 510-516. http://onlinelibrary.wiley.com/doi/10.1111/j.1365-3059.1990.tb02527.x/pdf http://dx.doi.org/10.1111/j.1365-3059.1990.tb02527.x

[10] Yoder, O.C. (1980) Toxins in Pathogenesis. Annual Review of Phytopathology, 18, 103-129. http://dx.doi.org/10.1146/annurev.py.18.090180.000535

[11] Wolpert, T.J., Dunkle, L.D. and Ciuffetti, L.M. (2002) Host-Selective Toxins and a Virulence Determinants: What's in a Name? Annual Review of Phytopathology, 40, 251-285. http://www.ncbi.nlm.nih.gov/pubmed/12147761

[12] Howlett, B.J. (2006) Secondary Metabolite Toxins and Nutrition of Plant Pathogenic Fungi. Current Opinion in Plant Biology, 9, 371-375. http://dx.doi.org/10.1016/j.pbi.2006.05.004

[13] Maude, R.B. and Humpherson-Jones, F.M. (1980) Studies on the Seed-Borne Phases of Dark Leaf Spot (Alternaria brassicicola) and Grey Leaf Spot (Alternaria brassicae) of Brassicas. Annals of Applied Biology, 95, 331-319. http://onlinelibrary.wiley.com/doi/10.1111/j.1744-7348.1980.tb04752.x/pdf http://dx.doi.org/10.1111/j.1744-7348.1980.tb04752.x

[14] Ellis, M.B. (1971) Dematiaceous Hyphomycetes. Commonwealth Mycological Institute, Kew.

[15] Ellis, M.B. (1976) More Dematiaceous Hyphomycetes. Commonwealth Mycological Institute, Kew.

[16] Ellis, M.B. (1985) Microfungi on Land Plants: An Identification Handbook. Croom Helm Ltd., Kent, UK.

[17] Gilchrist-Saavedra, L., Fuentes-Davila, G. and Martinez-Cano, C. (1997) Practical Guide to the Identification of Selected Diseases of Wheat and Barley. D.E. CIMMYT, Mexico. http://www.org/xmlui/bitstream/handle/10883/3219/64331.pdf

[18] Williams-Woodward, J. (2001) Simplified Fungi Identification Key. Special Bulletin 37, The University of Georgia. http://plantpath.caes.uga.edu/extension/documents/fungikey.pdf

[19] Crous, P.W., Gams, W., Stalpers, J.A., Robert, V. and Stegehuis, G. (2004) MycoBank: An Online Initiative to Launch Mycology into the 21st Century. Studies in Mycology, 50, 19-22. http://www.cbs.knaw.nl/images/ResearchGroups/Phytopathology/pdf/PDF\%20OP\%20NUMMER/203.pdf

[20] Humpherson-Jones, F.M. (1985) The Incidence of Alternaria spp. and Leptosphaeria maculans in Commercial Brassica Seed in the United Kingdom. Plant Pathology, 34, 385-390. 
http://onlinelibrary.wiley.com/doi/10.1111/j.1365-3059.1985.tb01377.x/pdf http://dx.doi.org/10.1111/j.1365-3059.1985.tb01377.x

[21] Rimmer, S.R. and Buchwaldt, H. (1995) Diseases. In: Kimber, D. and McGregor, D.I., Eds., Brassica OilseedsProduction and Utilization, CAB International, Wallingford, UK, 111-140.

[22] Rude, S.V., Duczek, L.J. and Seidle, E. (1999) The Effect of Alternaria brassicae, Alternaria raphani and Alternaria alternata on Seed Germination of Brassica rapa Canola. Seed Science and Technology, 27, 795-798.

[23] Tohyama, A., Kohmoto, K., Yu, S.H. and Tsuda, M. (1991) Alternaria on Cruciferous Plants 2. Alternaria Species on Seed of Chinese Radish and Their Pathogenicity. Transactions of the Mycological Society of Japan, 32, 247-258.

[24] Kucharek, T. (1994) Alternaria Diseases of Crucifers. Fact Sheet PP-34. Cooperative Extension Service, University of Florida, Gainesville, 3 p. http://plantpath.ifas.ufl.edu/extension/fact-sheets/pdfs/pp0034.pdf

[25] Tsuge, T., Harimoto, Y., Akimitsu, K., Ohtani, K., Kodama, M., Akagi, Y., Egusa, M., Yamamoto, M. and Otani, H. (2013) Host-Selective Toxins Produced by the Plant Pathogenic Fungus Alternaria alternata. FEMS Microbiology Reviews, 37, 44-66. http://femsre.oxfordjournals.org/content/37/1/44.long http://dx.doi.org/10.1111/j.1574-6976.2012.00350.x

[26] Otani, H., Kohmoto, K. and Kodama, M. (1995) Alternaria Toxins and Their Effects on Host Plants. Canadian Journal of Botany, 73, 453-458.

http://www.nrcresearchpress.com/doi/abs/10.1139/b95-282?journalCode=cjb1\#.VYNlRfmqqkq http://dx.doi.org/10.1139/b95-282

[27] Cooke, D.E.L., Jenkins, P.D. and Lewis, D.M. (1997) Production of Phytotoxic Spore Germination Liquids by Alternaria brassicae and A. brassicicola and Their Effect on Species of the Family Brassicaceae. Annals of Applied Biology, 131, 413-426. http://onlinelibrary.wiley.com/doi/10.1111/j.1744-7348.1997.tb05169.x/pdf http://dx.doi.org/10.1111/j.1744-7348.1997.tb05169.x

[28] MacKinnon, S.L., Keifer, P. and Ayer, W.A. (1999) Components from the Phytotoxic Extract of Alternaria brassicicola, a Black Spot Pathogen of Canola. Phytochemistry, 51, 215-221. http://dx.doi.org/10.1016/S0031-9422(98)00732-8 